\section{Self-poisoning: psychiatric assessment by junior staff}

A report by Gardner et al suggested that a junior physician, trained by psychiatrists, can assess the needs of self-poisoned patients, thereby obviating the need for routine assessment by psychiatrists. ${ }^{1}$ As few psychiatric units are willing to adopt this suggestion and the ment. We thought that in a city where there is a shortage of acute medical beds the admissions policy was difficult to justify.

We were not surprised to find that junior doctors would have referred almost twice as many cases to the social services as the psychiatrists actually did. This is probably because the two parties assessed the patients at different times. Psychiatrists saw $59 \%$ of the cases more than 12 hours after the event. By this time relatives are rarely available for interview and the patient more eager to forget. Coupled with Gardner's work, the knowledge that junior physicians

Agreement between decisions made by psychiatrists and junior doctors ( $\mathcal{~ D s ) ~ o n ~ m a n a g e m e n t ~ o f ~}$ 204 cases of self-poisoning

\begin{tabular}{|c|c|c|c|c|c|c|c|}
\hline \multirow{2}{*}{ JDs' opinion } & \multicolumn{5}{|c|}{ Psychiatrists' opinion } & \multirow{2}{*}{$\begin{array}{c}{ }_{0 \text { in which }} \\
\text { psychiatrist } \\
\text { agreed with } \\
\text { JDs }\end{array}$} & \multirow{2}{*}{$\begin{array}{c}\% \text { of } \\
\text { false- } \\
\text { positives }\end{array}$} \\
\hline & Admission & Outpatients & $\begin{array}{c}\text { Social } \\
\text { services }\end{array}$ & $\begin{array}{c}\text { No } \\
\text { action }\end{array}$ & Total & & \\
\hline $\begin{array}{l}\text { Admission } \\
\text { Outpatients } \\
\text { Social services } \\
\text { No action }\end{array}$ & $\begin{array}{c}25^{*} \\
6\end{array}$ & $\begin{array}{c}12 \\
85^{*} \\
5 \\
10 \\
\end{array}$ & $1^{3} 1^{*}$ & $\begin{array}{l}24 \\
23 *\end{array}$ & $\begin{array}{r}37 \\
118 \\
16 \\
33 \\
\end{array}$ & $\begin{array}{l}68 \\
72 \\
69 \\
70\end{array}$ & $\begin{array}{l}32 \\
28 \\
31 \\
30\end{array}$ \\
\hline Total & 31 & 112 & 14 & 47 & 204 & & \\
\hline $\begin{array}{l}\text { " in which JDs agreed } \\
\text { with psychiatrist } \\
\text { ". of false-negatives }\end{array}$ & $\begin{array}{l}81 \\
19\end{array}$ & $\begin{array}{l}76 \\
24\end{array}$ & $\begin{array}{l}79 \\
21\end{array}$ & $\begin{array}{l}49 \\
51\end{array}$ & & & \\
\hline
\end{tabular}

* Patients in whom there was total agreement.

DHSS has not altered its policy," we have continued our investigations into care for self-poisoned patients. ${ }^{3}{ }^{4}$ We report a study designed to test the ability of a newly qualified house officer to assess these patients.

\section{Patients, methods, and results}

All cases of deliberate self-poisoning presenting to the Newcastle Genera Hospital over a six-month period were studied. Junior doctors completed a questionnaire, which was then returned for analysis before routine psychiatric referral. This assessment was later compared with the psychiatric report. Junior doctors were asked only about initial management, which falls into four categories: (1) admission to a psychiatric hospital, (2) psychiatric outpatient appointment, (3) referral to the social services department, and (4) no action. No specialist instruction was given to the junior doctors, and subsequent management was as normal.

During the six months 236 patients presented to the casualty department after self-poisoning. Thirty-two were discharged without being admitted. Of the remaining 204, $184\left(90^{\circ}\right)$ were admitted for medical or psychiatric reasons while $20\left(10^{\circ}{ }_{1}\right)$ were admitted solely for assessment by a psychiatrist (to comply with DHSS recommendations ${ }^{2}$ ). The table shows the opinions of junior doctors and psychiatrists on initial management. Agreement between the junior doctors and psychiatrists was considerable in three categories, with $81 \%$ concordance for those patients requiring admission to a psychiatric unit. Junior doctors appeared to err on the side of caution, particularly for those patients in the "no-action" group, where the measure of disagreement was significant $\left(\gamma^{2}=4.97, P<0.05\right.$; McNeman's test $)$. Junior doctors would also have referred 28 patients in the outpatient group to the social services (in contrast to social services alone) compared with eight patients whom the psychiatrist referred to both. Overall the junior doctors would have referred 44 patients to social services compared with the 22 referred by the psychiatrists.

\section{Comment}

Medical training has changed greatly since the publication of the Hill report ${ }^{5}$ and the subsequent recommendations of the DHSS on managing patients with self-poisoning. ${ }^{2}$ The current emphasis on psychiatric and sociological aspects of disease in undergraduate and postgraduate training has made many physicians feel competent to assess these patients. Evidence is accumulating that the semi-legislative recommendations are no longer necessary. Ten per cent of the cases studied were admitted for neither medical nor psychiatric reasons but solely to conform to the recommendations of the DHSS. This proportion would have been higher, but some doctors ignored these recommendations and discharged patients from the casualty depart- are capable of selecting most patients who would benefit from inpatient psychiatric care suggests that the present admissions policy could be changed. Junior doctors are already adequately trained to permit this change.

We thank Mrs D Weightman for statistical help, and the junior doctors who participated in this study.

${ }^{1}$ Gardner, R, et al, British Medical fournal, 1978, 2, 1392.

2 Ministry of Health, Attempted Suicide, HM (61) 94. London, Ministry of Health, 1961.

${ }^{3}$ Blake, D R, and Mitchell, J R A, British Medical fournal, 1978, 1, 1032.

${ }^{4}$ Blake, D R, and Bramble, M G, British Medical Yournal, 1978, 2, 1788.

${ }^{5}$ Central and Scottish Health Services Councils, Hospital Treatment of Acute Poisoning. London, HMSO, 1968.

(Accepted 2 May 1979)

Department of Medicine, Royal Victoria Infirmary, Newcastle upon Tyne NE1 4I.P

D R BLAKE, MB, MRCP, honorary senior registrar

M G BRAMBLE, MB, MRCP, senior registrar

\section{Pulmonary oedema in falciparum malaria}

Pulmonary oedema is a serious and often fatal complication of Plasmodium falciparum malaria. It may be caused by fluid overload, especially with renal failure, but has also occurred without clinical evidence of hypervolaemia..$^{1-3}$ In only one case has absence of volume overload been suggested from measurement of pulmonary capillary wedge pressure. ${ }^{3}$ We report a further case, in which haemodynamic data supported a pathogenetic mechanism other than fluid overload for this complication.

\section{Case report}

A 19-year-old man presented in coma, with temperature $38.5^{\circ} \mathrm{C}$, neck stiffness, and bilateral papilloedema. He was pale and jaundiced and had hepatosplenomegaly. Investigations showed: haemoglobin concentration $3.9 \mathrm{~g} / \mathrm{dl}$; white cell count $7 \cdot 1 \times 10^{9} / 1\left(7100 / \mathrm{mm}^{3}\right)$; platelet count $60 \times 10^{9} / 1$ 
$\left(60000 / \mathrm{mm}^{3}\right)$; prothrombin index $50 \%$; raised concentration of fibrinogen degradation products $(100-400 \mathrm{mg} / \mathrm{l})$; blood urea concentration $30.2 \mathrm{mmol} / \mathrm{l}$ $(182 \mathrm{mg} / 100 \mathrm{ml})$; normal serum electrolyte values; total serum bilirubin concentration $64 \mu \mathrm{mol} / 1(3.7 \mathrm{mg} / 100 \mathrm{ml})$, direct bilirubin concentration $22 \mu \mathrm{mol} / 1(1.3 \mathrm{mg} / 100 \mathrm{ml})$; serum albumin concentration $25 \mathrm{~g} / 1$; and serum osmolality $290 \mathrm{mmol}(\mathrm{mosmol}) / \mathrm{kg}$. While breathing air his arterial $\mathrm{pH}$ was $7 \cdot 17$, bicarbonate concentration $5.5 \mathrm{mmol}(\mathrm{mEq}) / 1, \mathrm{PCO}_{2} 2 \mathrm{kPa}$ $\left(15 \mathrm{~mm} \mathrm{Hg}\right.$ ), and $\mathrm{Po}_{2} 11.6 \mathrm{kPa}\left(87 \mathrm{~mm} \mathrm{Hg}\right.$ ) (normal value for $\mathrm{Po}_{2}$ in Johannesburg $10 \mathrm{kPa}(75 \mathrm{~mm} \mathrm{Hg})$ ). An electrocardiogram was normal. Chest radiography showed a left upper-lobe infiltrate thought to be due to infection. A peripheral blood smear was heavily infected with $P$ falciparum. Treatment was instituted with intravenous chloroquine $2 \cdot 1 \mathrm{~g}$ over 72 hours and intravenous dexamethasone $4 \mathrm{mg}$ six-hourly. Sodium bicarbonate was given for the metabolic acidosis, and the anaemia was corrected with packed cells. Intravenous ampicillin was used for the possible chest infection. Recovery of consciousness and elimination of the parasitaemia occurred by 48 hours. Prothrombin index and platelet count returned to normal, and blood urea concentration fell. Average daily fluid intake was 3.5 1 and output $3 \cdot 11$.

Seventy-two hours after admission the patient suddenly developed tachypnoea and cyanosis with diffuse pulmonary crepitations. There was no evidence of heart failure. Chest radiography showed extensive bilatera confluent opacification (figure). Arterial $\mathrm{Po}_{2}$ while breathing $80 \%$ oxygen

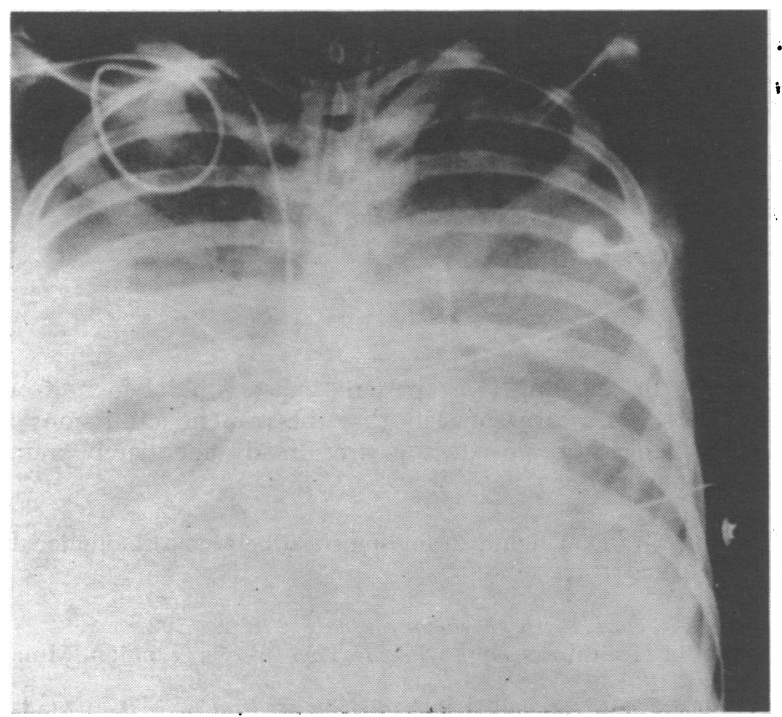

Radiograph showing extensive bilateral confluent opacification.

was $6 \mathrm{kPa}$ ( $45 \mathrm{~mm} \mathrm{Hg}$ ). A Swan-Ganz catheter was introduced and pressures measured: right atrium $2 \mathrm{~mm} \mathrm{Hg}$, pulmonary wedge $5 \mathrm{~mm} \mathrm{Hg}$; cardiac output was $71 / \mathrm{min}$ (cardiac index $41 / \mathrm{min} / \mathrm{m}^{2}$ ). The trachea was intubated and continuous positive airway pressure of $15 \mathrm{ml}$ water applied with intermittent mandatory ventilation. Penicillin, cloxacillin, and gentamicin were given intravenously. Arterial $\mathrm{Po}_{2}$ improved rapidly to $10.7 \mathrm{kPa}(80 \mathrm{~mm} \mathrm{Hg})$ while breathing $50 \%$ oxygen. Pulmonary wedge pressure never exceeded $10 \mathrm{~mm} \mathrm{Hg}$. The pulmonary opacification had almost completely resolved after 24 hours. The patient was discharged 10 days later with a normal chest $x$-ray appearance.

\section{Comment}

We have shown that pulmonary oedema may occur in falciparum malaria in the absence of a raised pulmonary wedge pressure. Disseminated intravascular coagulation, uraemia, and intracranial disease may precipitate the oedema by causing microvascular damage. ${ }^{4}$ Small increases in pulmonary capillary hydrostatic pressure lead to pronounced extravasation of fluid into the lungs when microvascular permeability is abnormal. ${ }^{5}$ Hence hypoalbuminaemia and excessive fluid therapy might have been contributory despite the normal pulmonary wedge pressure.

Pulmonary oedema in falciparum malaria has a high mortality rate. ${ }^{2}$ Accurate haemodynamic monitoring via a Swan-Ganz catheter may be of value when complications such as renal failure, cerebral abnormality, and disseminated intravascular coagulation occur Fluids should be administered cautiously in the presence of these complications. Diuretic treatment aimed at lowering pulmonary wedge pressure may be ineffective in the absence of fluid overload. The main object of treatment is to oxygenate the blood adequately with safe concentrations of inspired oxygen until the abnormality of the pulmonary microcirculation has resolved and reabsorption of the oedema fluid has occurred. This may be achieved by efficient ventilation with the judicious use of continuous positive airway pressure.

We thank D P Myburgh, of No 1 Military Hospital, Voortrekkerhoogte, for permission to report this case; and Anita Wise for help in preparing the manuscript.

Requests for reprints should be addressed to: Professor S Zwi, Department of Medicine, Medical School, Hospital Street, Johannesburg, 2001 South Africa.

1 Brooks, M H, et al, New England fournal of Medicine, 1968, 279, 732.

2 Punyagupta, S, et al, American fournal of Tropical Medicine and Hygiene, $1974,23,551$.

${ }^{3}$ Fein, I A, Rackow, E C, and Shapiro, L, American Review of Respiratory Disease, 1978, 118, 425.

4 Robin, E D, Cross, C E, and Zelis, R, New England fournal of Medicine, 1973, 288; 292.

5 Staub, N C, American Reviezv of Respiratory Disease, 1974, 109, 358.

(Accepted 16 May 1979)

Department of Medicine, University of the Witwatersrand, and General Hospital, Johannesburg, South Africa

R W MARTELL, BSC, MB, registrar

J KALLENBACH, MB, MRCP, senior physician

S ZWI, BSC, FRCP, professor of respiratory medicine and principal physician

\section{Fetal death in utero managed with vaginal prostaglandin $\mathrm{E}_{2}$ gel}

Fetal death in utero warrants early induction of abortion or delivery to reduce emotional distress and the risk of intrauterine sepsis or consumption coagulopathy. An expeditious method causing a minimum of trauma is provided by intravenous ${ }^{1}$ or extra-amniotic ${ }^{2}$ prostaglandin. In an effort to reduce the side effects of intravenous infusion and simplify extra-amniotic instillation we have evaluated the efficacy of prostaglandin $\mathrm{E}_{2}\left(\mathrm{PGE}_{2}\right)$ in viscous gel instilled vaginally.

\section{Patients, methods, and results}

Fifty women aged 18-36 years with confirmed fetal death in utero were treated; 28 were primigravidae and 22 multigravidae (see table). PGE (Prostin $\mathrm{E}_{2}$ ) was administered in $10 \mathrm{ml}$ volumes of a $6 \%$ aqueous solution of hydroxyethylmethylcellulose (Tylose $\mathrm{MH} 300$ ). Gel preparation and administration were as described. ${ }^{3}$ Dosage varied with uterine size (estimated as gestational-age equivalent), $15 \mathrm{mg}$ being used when under 29 weeks and $5 \mathrm{mg}$ when 29 weeks or more. $\mathrm{PGE}_{2}$ gel was usually instilled between 1500 and 2100 . Diamorphine $10 \mathrm{mg}$ or papaveretum $15 \mathrm{mg}$ was given intramuscularly when analgesia was required, vaginal examination having been performed first. Next morning if expulsion had not occurred an intravenous infusion of oxytocin was begun: those with uterine size below 29 weeks received a constant $100 \mathrm{mU} / \mathrm{min}$, while the others began with $4 \mathrm{mU} / \mathrm{min}$ increasing as required to $32 \mathrm{mU} / \mathrm{min}$. Patients whose uterine size was 29 weeks or more underwent amniotomy when necessary once the cervix was dilated at least $5 \mathrm{~cm}$. Surgical evacuation was performed only when expulsion of the placenta was incomplete.

Details of patients treated with $P G E_{2}$ gel

\begin{tabular}{|c|c|c|c|}
\hline & & \multicolumn{2}{|c|}{ Dosage of $\mathrm{PGE}_{2}$} \\
\hline & & $\begin{array}{l}5 \mathrm{mg} \\
(\mathrm{n}=23)\end{array}$ & $\begin{array}{l}15 \mathrm{mg} \\
(\mathrm{n}=27)\end{array}$ \\
\hline Gestational age (weeks) & $\left\{\begin{array}{l}\text { Range } \\
\text { Mean }\end{array}\right.$ & $\begin{array}{c}29-42 \\
36 \cdot \frac{2}{2}\end{array}$ & $\begin{array}{c}15-33 \\
24 \cdot 7\end{array}$ \\
\hline Uterine size (gestation equivalent) & Range & $\begin{array}{c}29-40 \\
34 \cdot 8\end{array}$ & $\begin{array}{c}11-28 \\
19 \cdot 7\end{array}$ \\
\hline Calculated time since fetal death (days) & Range & $1-28$ & $1-42$ \\
\hline Calculated time since letal deatn (days) & Mean & $7 \cdot 3$ & $33 \cdot 0$ \\
\hline Treatment-delivery/abortion interval $(\mathrm{h})$ & $\left\{\begin{array}{l}\text { Range } \\
\text { Mean }\end{array}\right.$ & $\begin{array}{c}4 \cdot 0-33 \cdot 5 \\
14 \cdot 7\end{array}$ & $\begin{array}{c}3 \cdot 4-40 \cdot 0 \\
15 \cdot 5\end{array}$ \\
\hline Duration of labour (h) & $\left\{\begin{array}{l}\text { Range } \\
\text { Mean }\end{array}\right.$ & $\begin{array}{c}1 \cdot 4-23 \cdot 8 \\
6 \cdot 2\end{array}$ & $\overline{-}$ \\
\hline \multicolumn{2}{|c|}{$\begin{array}{l}\text { No }\left({ }^{\circ}, 1\right) \text { of mothers needing intravenous } \\
\text { oxytocin }\end{array}$} & $9(39 \cdot 1)$ & $10(37 \cdot 0)$ \\
\hline \multicolumn{2}{|c|}{$\begin{array}{l}\text { Analgesia }\left\{\begin{array}{l}\text { No }(\%) \text { not needing injections } \\
\text { No }(0) \text { needing two or more injections }\end{array}\right. \\
\text { No }(\%) \text { with gastrointestinal side effects }\end{array}$} & $\begin{array}{c}1(4 \cdot 3) \\
7(30 \cdot 4) \\
0\end{array}$ & $\begin{array}{l}10(37 \cdot 0) \\
2(7 \cdot 4) \\
4(14 \cdot 8)\end{array}$ \\
\hline
\end{tabular}

